\title{
On the Relationship between Iranian L2 Teachers' Pedagogical Beliefs and L2 Learners' Attitudes
}

\author{
Maryam Sharajabian ${ }^{1} \&$ Mahmood Hashemian ${ }^{1}$ \\ 1 Department of Foreign Languages, Isfahan (Khorasgan) Branch, Islamic Azad University, Isfahan, Iran \\ Correspondence: Mahmood Hashemian, Islamic Azad University, Isfahan (Khorasgan) Branch, Isfahan, Iran. Tel: \\ 98-913-266-3269. E-mail: m72h@hotman.com
}

\author{
Received: August 16, 2015 Accepted: October 2, 2015 Online Published: October 3, 2015 \\ doi:10.5539/elt.v8n11p56 \\ URL: http://dx.doi.org/10.5539/elt.v8n11p56
}

\begin{abstract}
The present study employed a descriptive survey design to investigate L2 learners' attitudes towards language learning, and the possible effects of teachers' beliefs on learners' attitudes. Participants were chosen from among 2 groups: Twenty EFL teachers were asked to take part in this study and 80 from a pool of 213 learners at 2 language schools who were chosen to fill out the learners' attitude questionnaire. The teachers were subsequently placed at/in 3 groups of high-opinion group (HOG), moderate group (MG), and low-opinion group (LG), and the attitudes of the learners of these 3 groups of teachers were compared to uncover the possible impact of teacher beliefs on learner attitudes. The relationship between the teachers' beliefs and the learners' attitudes was analyzed, and it that showed there was a statistically significant difference in the learners' attitude scores for HOG, MG, and LOG. Analysis of the data showed that the learners of the HOG teachers gained significantly higher attitude scores than the learners of the MG teachers. Simply put, it was found that EFL teachers' beliefs can influence their learners' attitudes about language learning. Language teachers should learn about the effect of their beliefs and experience it and become more aware of practicing them.
\end{abstract}

Keywords: EFL teachers' beliefs, Learners' attitude, language learning, High-opinion group (HOG), Moderate group (MG), Low-opinion group (LOG)

\section{Introduction}

Over the past 30 years, research has suggested that teachers' beliefs heavily influence their pedagogical practice (e.g., Borg, 2003; Mangubhai et al., 2004; Ng \& Farrell, 2003), their instructional decisions in the classroom (Tillema, 2000), and acceptance and uptake of new approaches, techniques and activities (Donaghue, 2003).

Teachers' beliefs are important concepts in understanding their thought processes, instructional practices, and change and learning to teach. As the research on teaching shifts its focus from products to processes, the research on teachers' cognition, since the late 1970s has progressed through three distinct stages, each characterized by an emphasis on a particular domain of teachers' cognitive life: teachers' planning, teachers' interactive thoughts and decisions, and teachers' beliefs and implicit theories (Clark \& Peterson, 1986).

Kara (2009) stated that attitudes towards learning — besides opinions and beliefs — have an obvious influence on students' behaviors and, consequently, on their performance. It is argued that those students who possess positive beliefs about language learning have a tendency to increase more positive attitudes towards language learning. Conversely, negative beliefs may lead to class anxiety, low cognitive achievement, and negative attitudes (Victori \& Lockhart, 1995).

Reid (2003) says that "attitudes are important to teachers because they cannot be neatly separated from study" (p. 33). Attitude is considered as an essential factor influencing language performance (Visser, 2008). Achievement in an L2 relies not only on intellectual capacity, but also on/in the learner's attitudes towards language learning. This means that learning a language should be approached primarily as a social and psychological phenomenon rather than as a purely academic one.

Wenden (1991) proposes a broader definition of attitudes and classifies attitude into three components: cognitive, affective, and behavioral. The cognitive component is made up of the beliefs and thoughts about the object of the 
attitude. The affective component involves the person's emotions towards an object, likes or dislikes, with or against. Finally, the behavioral component refers to one's consisting actions or tendency to adopt special learning behaviors (Zainol Abidin, Pour-Mohammadi, \& Alzwari, 2012).

Despite the existence of a large body of research literature on teachers' beliefs and learners' attitudes, there have been only a limited number of studies on the relationship between teachers' beliefs and learners' attitudes. English is learnt by more nonnative speakers as an L2, than the native speakers (Canagarajah, 2005). As learning a language, especially English, is an important issue in today's globalized world, this study aimed to find out if there is a positive relationship between EFL teachers' beliefs on how their students learn English and how these beliefs are related to the students' attitudes. The attitude concept is considered as an essential component in language learning. Students' attitude toward learning English can characterize their teachers' beliefs, and it is related to teachers' attitude who try to attract their students' motivation to learn English in the best way. Other studies that propose that teachers are an important influence on learners' motivation include Dörnyei's (1994) study.

Attitude is considered as one of the most important components of language learning. Regarding L2 learners' attitude towards English language learning, it is obvious that most of L2 learners in EFL contexts learn English as a compulsory subject. It is recommended that teachers in EFL classrooms motivate their learners towards the English language learning by highlighting its importance. Teachers should be responsive to their learners' attitudes and value their attitudes and preconceptions, as they can affect their success in L2 learning. Briefly, EFL teachers should involve learners in activities that build up positive attitudes towards learning English.

\section{Review of Literature}

There is a general consensus and a substantial body of evidence indicating that the beliefs teachers have are strongly influential in how they approach teaching and learning, and that they guide the way teachers act in a classroom (Borg, 2006; Calderhead, 1996). More than two decades ago, Clark and Peterson (1986) stated that the beliefs teachers have about teaching and learning affect their decision-making and planning processes, and that the approaches they adopt when teaching, the tasks and the materials they choose to implement in classrooms, and their relationships with the students are, to a great extent, determined by their beliefs. Many researchers have also found that beliefs exert such an influence and they guide the way that teachers teach (Almarza, 1996; Erkmen, 2010; Nespor, 1987).

Kim and Mcgarry (2014) stress "attitudes generally relates to a person's desire to study and interest" (p. 28). Teachers should pay more attention to student attitudes as they affect student success, as Al-Tamimi and Shuib (2009) emphasize "attitudes play a very crucial role in language learning as they would appear to influence students' success or failure in their learning" (p. 33). In Soleimani and Hanafi's (2013) study, it is recommended that teachers should be responsive to learners' attitudes and value their students' attitudes and preconceptions, as it can affect their success in L2 learning. Hassan (1996) also shows a significant correlation between attitudes towards English and English achievement.

\subsection{Attitude}

An attitude could be generally defined as the way a person responds to his or her environment, either positively or negatively. The definition of attitude is, nonetheless, a source of some discussion and debate. When defining attitude, it is helpful to bear two useful conflicts in mind: the existence of ambivalence or differences of attitude towards a given person, object, situation, and so on from the same person-sometimes at the same time. In the following, the three aspects of attitude concept (i.e., behavioral, cognitive, and emotional) are briefly described.

\subsubsection{Behavioral Aspect of Attitude}

The behavioral aspect of attitude deals with the way one behaves and reacts in particular situations. In fact, the successful language learning enhances L2 learners to identify themselves with the native speakers of that language and acquire or adopt various aspects of behaviors which characterize the members of the L2 community.

\subsubsection{Cognitive Aspect of Attitude}

This aspect of attitude involves the beliefs of L2 learners about the knowledge that they receive and their understanding in the process of language learning. 


\subsubsection{Emotional Aspect of Attitude}

Attitude can help L2 learners to express whether they like or dislike the objects or surrounding situations. It is agreed that the inner feelings and emotions of L2 learners influence their perspectives and their attitudes towards an L2 (Choy \& Troudi, 2006).

\subsection{Teachers'Beliefs}

Studies of teacher beliefs reveal that teachers have beliefs about all aspects of their work. Calderhead (1996) argues that there are five main areas in which teachers have been found to hold significant beliefs, including beliefs about learners and learning, teaching, subjects or curriculum, learning to teach, and about the self and the nature of teaching. He also notes that these five areas are closely related and may well be interconnected. The structure of teachers' beliefs is by no means uniform or simple.

Afterward, based upon the abovementioned deliberations, the following questions stand out:

1) What are Iranian EFL learners' attitudes toward learning the English language in terms of their behavioral, cognitive and emotional?

2) What is the relationship between Iranian teachers' beliefs and learners' attitudes?

\section{Method}

\subsection{Participants}

The participants were chosen from among two major groups. The first major participants were 20 language teachers majoring in English translation or teaching methodology. There were also 80 student participants in this study who were selected from a pool of 213 learners at two different language schools. They were all classified as intermediate language learners

\subsection{Materials}

The questionnaire used in the present study was designed to evaluate students' attitudes towards English. The items of this questionnaire were partly adapted from the attitude questionnaire test employed in a study by Boonrangsri, Chuaymankhong, Rermyindee, and Vongchittpinyo (2004). Other items were taken from Attitude and Motivation Test Battery (AMTB; Gardner, 1985). There were 45 items concerning language attitudes in terms of: behavioral, cognitive, and emotional aspects of attitude. Overall, 30 items were positive and 15 items were negative. The items were put in a 5-point Likert scale from level 1 (Strongly Disagree) to level 5 (Strongly Agree) (see Appendix)

A semistructured interview was conducted with the teacher participants. Although it is seen that beliefs can be investigated quantitatively and qualitatively, using merely quantitative methods in investigating beliefs has received criticism. According to Maiklad (2001), using quantitative methods is not suitable for issues that require reflective thinking. Considering the nature of beliefs, it is clear that they have complex nature that might not be investigated through predetermined questions. It is essential to interact with individuals so as to ask questions according to their responses that will enable researchers to understand individual's beliefs thoroughly.

To address this, a semistructured interview was used in this study. In this respect, the researchers, in the interview section, asked some open-ended question questions during the interviews. The researchers only intervened when the talk became irrelevant for the scope of this study, and why questions were asked to understand the reasons behind a situation. The Teachers' Beliefs Questionnaire data were used to work out a possible pattern and to find the information about the teachers' beliefs. The emerging themes from the interview data were used to discuss their teaching approaches and underlying beliefs about language learning. Based on their beliefs, they were divided into three groups.

\subsection{Procedure}

\subsubsection{Phase One}

The student participants who took part in this study were 80 intermediate L2 learners who had enrolled in English courses in two language centers. They were all the students of the 20 teacher participants of this study. To collect the data from the student participants in both institutes, the questionnaire was distributed among the participants and they were required to answer the closed-ended questions based on their past experiences of participating in language classes. The students were also told that they could ask any questions about whatever they felt ambiguous. Even a Persian version of the attitude questionnaire was prepared to leave no point unclear 
for the student participants to answer the questions.

\subsubsection{Phase Two}

For the data collection of the teacher participants, they were asked to participate in a semistructured interview. Although it is seen that beliefs can be investigated quantitatively and qualitatively, using merely quantitative methods in investigating beliefs has received criticism.

\subsection{Data Analysis}

First, the teachers' semistructured interview was used to work out a possible pattern and to find information about their beliefs. Also, the teachers were divided into three groups of high-opinion group (HOG), moderate group (MG), and low-opinion group (LOG). The data obtained from the Students' Attitude Questionnaire were analyzed in terms of mean, percentages, and frequencies for 80 students. The collected data were also analyzed by being subjected to SPSS program. The attitude scores of the three groups of learners were, then, compared via one-way between groups ANOVA, with a .05 level of significance.

\section{Results}

\subsection{Results for the First Research Question}

Table 1. Results of learners' attitudes toward the behavioral aspect of the questionnaire

\begin{tabular}{|c|c|c|c|c|c|c|c|}
\hline No. & Frequency/Percent & Strongly Disagree & Disagree & No Idea & Agree & Strongly Agree & Mean \\
\hline \multirow[t]{2}{*}{5} & Frequency & 32 & 19 & 12 & 9 & & \multirow[t]{2}{*}{2.77} \\
\hline & Percent & $40 \%$ & $23.7 \%$ & $15 \%$ & $11.25 \%$ & $10 \%$ & \\
\hline \multirow[t]{2}{*}{6} & Frequency & 6 & & & 29 & & \multirow[t]{2}{*}{3.53} \\
\hline & Percent & $7.5 \%$ & $12.5 \%$ & $21.25 \%$ & $36.25 \%$ & $22.5 \%$ & \\
\hline \multirow[t]{2}{*}{7} & Frequency & 1 & 4 & & 27 & & \multirow[t]{2}{*}{4.25} \\
\hline & Percent & $1.25 \%$ & $5 \%$ & $11.25 \%$ & $33.75 \%$ & $48.75 \%$ & \\
\hline \multirow[t]{2}{*}{12} & Frequency & & 2 & & 29 & 42 & \multirow[t]{2}{*}{4.33} \\
\hline & Percent & $2.5 \%$ & $2.5 \%$ & $6.25 \%$ & $36.25 \%$ & $52.5 \%$ & \\
\hline \multirow[t]{2}{*}{13} & Frequency & 5 & 4 & & 28 & 36 & \multirow[t]{2}{*}{4.20} \\
\hline & Percent & $6.25 \%$ & $5 \%$ & $8.75 \%$ & $35 \%$ & $45 \%$ & \\
\hline \multirow[t]{2}{*}{17} & Frequency & 9 & 3 & & 28 & & \multirow[t]{2}{*}{3.86} \\
\hline & Percent & $11.25 \%$ & $3.75 \%$ & $11.25 \%$ & $35 \%$ & $38.75 \%$ & \\
\hline \multirow[t]{2}{*}{18} & Frequency & 5 & 4 & 16 & 23 & 32 & \multirow[t]{2}{*}{3.91} \\
\hline & Percent & $6.25 \%$ & $5 \%$ & $20 \%$ & $28.75 \%$ & $40 \%$ & \\
\hline \multirow[t]{2}{*}{19} & Frequency & & 4 & & & & \multirow[t]{2}{*}{3.86} \\
\hline & Percent & $6.25 \%$ & $5 \%$ & $21.25 \%$ & $31.25 \%$ & $36.25 \%$ & \\
\hline \multirow[t]{2}{*}{25} & Frequency & & 16 & & & & \multirow[t]{2}{*}{2.47} \\
\hline & Percent & $32.5 \%$ & $20 \%$ & $13.75 \%$ & $22.5 \%$ & $8.75 \%$ & \\
\hline \multirow[t]{2}{*}{26} & Frequency & 32 & & & & & \multirow[t]{2}{*}{2.05} \\
\hline & Percent & $40 \%$ & $31.25 \%$ & $13.75 \%$ & $13.75 \%$ & $1.25 \%$ & \\
\hline \multirow[t]{2}{*}{35} & Frequency & 0 & 0 & 0 & & & \multirow[t]{2}{*}{4.56} \\
\hline & Percent & $0 \%$ & $0 \%$ & $0 \%$ & $43.75 \%$ & $56.25 \%$ & \\
\hline \multirow[t]{2}{*}{37} & Frequency & & 4 & & 22 & 44 & \multirow[t]{2}{*}{4.27} \\
\hline & Percent & $2.5 \%$ & $5 \%$ & $10 \%$ & $27.5 \%$ & $55 \%$ & \\
\hline \multirow[t]{2}{*}{38} & Frequency & & & & 3 & 4 & \multirow[t]{2}{*}{1.38} \\
\hline & Percent & $62.5 \%$ & $22.5 \%$ & $6.25 \%$ & $3.75 \%$ & $5 \%$ & \\
\hline \multirow[t]{2}{*}{42} & Frequency & 49 & 14 & 10 & 5 & & \multirow[t]{2}{*}{1.71} \\
\hline & Percent & $61.25 \%$ & $17.5 \%$ & $12.5 \%$ & $6.25 \%$ & $2.5 \%$ & \\
\hline \multirow[t]{2}{*}{45} & Frequency & 62 & 12 & & 0 & 0 & \multirow[t]{2}{*}{1.30} \\
\hline & Percent & $77.5 \%$ & $15 \%$ & $7.5 \%$ & $0 \%$ & $0 \%$ & \\
\hline
\end{tabular}


The only item the answer of which could raise a few eyebrows is item $19(M=3.86)$, in which the learners stated that they put off their English homework as much as possible. All in all, the learners held positive attitudes towards language learning as far as the behavioral aspect of this issue was concerned.

Table 2. Results of learners' attitudes toward the cognitive aspect of the questionnaire

\begin{tabular}{|c|c|c|c|c|c|c|c|}
\hline No. & Frequency/Percent & Strongly Disagree & Disagree & No Idea & Agree & Strongly Agree & Mean \\
\hline 1 & $\begin{array}{l}\text { Frequency } \\
\text { Percent }\end{array}$ & $\begin{array}{l}2 \\
2.5 \%\end{array}$ & $\begin{array}{l}3 \\
3.75 \%\end{array}$ & $\begin{array}{l}7 \\
8.75 \%\end{array}$ & $\begin{array}{l}20 \\
25 \%\end{array}$ & $\begin{array}{l}48 \\
60 \%\end{array}$ & 4.36 \\
\hline 2 & $\begin{array}{l}\text { Frequency } \\
\text { Percent }\end{array}$ & $\begin{array}{l}0 \\
0 \%\end{array}$ & $\begin{array}{l}4 \\
5 \%\end{array}$ & $\begin{array}{l}22 \\
27.5 \%\end{array}$ & $\begin{array}{l}26 \\
32.5 \%\end{array}$ & $\begin{array}{l}28 \\
35 \%\end{array}$ & 3.97 \\
\hline 8 & $\begin{array}{l}\text { Frequency } \\
\text { Percent }\end{array}$ & $1.25 \%$ & $\begin{array}{l}2 \\
2.5 \%\end{array}$ & $\begin{array}{l}5 \\
6.25 \%\end{array}$ & $\begin{array}{l}30 \\
37.5 \%\end{array}$ & $\begin{array}{l}42 \\
52.5 \%\end{array}$ & 4.37 \\
\hline 9 & $\begin{array}{l}\text { Frequency } \\
\text { Percent }\end{array}$ & $\begin{array}{l}0 \\
0 \%\end{array}$ & $\begin{array}{l}2 \\
2.5 \%\end{array}$ & $\begin{array}{l}4 \\
5 \%\end{array}$ & $\begin{array}{l}18 \\
22.5 \%\end{array}$ & $\begin{array}{l}56 \\
70 \%\end{array}$ & 4.60 \\
\hline 20 & $\begin{array}{l}\text { Frequency } \\
\text { Percent }\end{array}$ & $1.25 \%$ & $\begin{array}{l}2 \\
2.5 \%\end{array}$ & $\begin{array}{l}5 \\
6.25 \%\end{array}$ & $\begin{array}{l}22 \\
27.5 \%\end{array}$ & $\begin{array}{l}50 \\
62.5 \%\end{array}$ & 4.47 \\
\hline 21 & $\begin{array}{l}\text { Frequency } \\
\text { Percent }\end{array}$ & $\begin{array}{l}15 \\
18.75 \%\end{array}$ & $\begin{array}{l}19 \\
23.75 \%\end{array}$ & $\begin{array}{l}20 \\
25 \%\end{array}$ & $\begin{array}{l}15 \\
18.75 \%\end{array}$ & $\begin{array}{l}11 \\
13.75 \%\end{array}$ & 2.85 \\
\hline 22 & $\begin{array}{l}\text { Frequency } \\
\text { Percent }\end{array}$ & $\begin{array}{l}47 \\
58.75 \%\end{array}$ & $\begin{array}{l}16 \\
20 \%\end{array}$ & $\begin{array}{l}11 \\
13.75 \%\end{array}$ & $\begin{array}{l}3 \\
3.75 \%\end{array}$ & $\begin{array}{l}3 \\
3.75 \%\end{array}$ & 1.73 \\
\hline 29 & $\begin{array}{l}\text { Frequency } \\
\text { Percent }\end{array}$ & $\begin{array}{l}6 \\
7.5 \%\end{array}$ & $\begin{array}{l}8 \\
10 \%\end{array}$ & $\begin{array}{l}15 \\
18.75 \%\end{array}$ & $\begin{array}{l}20 \\
25 \%\end{array}$ & $\begin{array}{l}31 \\
38.75 \%\end{array}$ & 3.75 \\
\hline 30 & $\begin{array}{l}\text { Frequency } \\
\text { Percent }\end{array}$ & $\begin{array}{l}0 \\
0 \%\end{array}$ & $\begin{array}{l}2 \\
2.5 \%\end{array}$ & $\begin{array}{l}11 \\
13.75 \%\end{array}$ & $\begin{array}{l}26 \\
32.5 \%\end{array}$ & $\begin{array}{l}41 \\
51.25 \%\end{array}$ & 4.32 \\
\hline 31 & $\begin{array}{l}\text { Frequency } \\
\text { Percent }\end{array}$ & $\begin{array}{l}24 \\
30 \%\end{array}$ & $\begin{array}{l}14 \\
17.5 \%\end{array}$ & $\begin{array}{l}14 \\
17.5 \%\end{array}$ & $\begin{array}{l}14 \\
17.5 \%\end{array}$ & $\begin{array}{l}14 \\
17.5 \%\end{array}$ & 3.00 \\
\hline 34 & $\begin{array}{l}\text { Frequency } \\
\text { Percent }\end{array}$ & $2.5 \%$ & $\begin{array}{l}7 \\
8.75 \%\end{array}$ & $\begin{array}{l}11 \\
13.75 \%\end{array}$ & $\begin{array}{l}28 \\
35 \%\end{array}$ & $\begin{array}{l}32 \\
40 \%\end{array}$ & 4.01 \\
\hline 36 & $\begin{array}{l}\text { Frequency } \\
\text { Percent }\end{array}$ & $\begin{array}{l}7 \\
8.75 \%\end{array}$ & $\begin{array}{l}5 \\
6.25 \%\end{array}$ & $\begin{array}{l}20 \\
25 \%\end{array}$ & $\begin{array}{l}23 \\
28.75 \%\end{array}$ & $\begin{array}{l}25 \\
31.25 \%\end{array}$ & 3.67 \\
\hline 39 & $\begin{array}{l}\text { Frequency } \\
\text { Percent }\end{array}$ & $\begin{array}{l}33 \\
41.25 \%\end{array}$ & $\begin{array}{l}18 \\
22.5 \%\end{array}$ & $\begin{array}{l}14 \\
17.5 \%\end{array}$ & $\begin{array}{l}9 \\
11.25 \%\end{array}$ & $\begin{array}{l}6 \\
7.5 \%\end{array}$ & 2.21 \\
\hline 40 & $\begin{array}{l}\text { Frequency } \\
\text { Percent }\end{array}$ & $\begin{array}{l}25 \\
31.25 \%\end{array}$ & $\begin{array}{l}26 \\
32.5 \%\end{array}$ & $\begin{array}{l}16 \\
20 \%\end{array}$ & $\begin{array}{l}9 \\
11.25 \%\end{array}$ & $\begin{array}{l}4 \\
5 \%\end{array}$ & 2.26 \\
\hline 41 & $\begin{array}{l}\text { Frequency } \\
\text { Percent }\end{array}$ & $\begin{array}{l}5 \\
6.25 \%\end{array}$ & $\begin{array}{l}8 \\
10 \%\end{array}$ & $\begin{array}{l}13 \\
16.25 \%\end{array}$ & $\begin{array}{l}20 \\
25 \%\end{array}$ & $\begin{array}{l}34 \\
42.5 \%\end{array}$ & 3.87 \\
\hline
\end{tabular}

The highest mean score in Table 2 belonged to item $9(M=4.60)$ which stated that the learners looked forward to studying more English in future. On the other hand, the lowest mean score was that of item $22(M=1.73)$, showing that the learners disagreed with the proposition that they studied English just to pass the exams. 
Table 3. Results of the participants' attitudes toward the emotional aspect of the questionnaire

\begin{tabular}{|c|c|c|c|c|c|c|c|}
\hline No. & Frequency/Percent & Strongly Disagree & Disagree & No idea & Agree & Strongly Agree & Mean \\
\hline \multirow[t]{2}{*}{3} & Frequency & 1 & 3 & 7 & 18 & 51 & \multirow[t]{2}{*}{4.21} \\
\hline & Percent & $1.25 \%$ & $3.75 \%$ & $8.75 \%$ & $22.5 \%$ & $63.75 \%$ & \\
\hline \multirow[t]{2}{*}{4} & Frequency & 4 & 0 & 6 & & & \multirow[t]{2}{*}{4.41} \\
\hline & Percent & $5 \%$ & $0 \%$ & $7.5 \%$ & $23.75 \%$ & $63.75 \%$ & \\
\hline \multirow[t]{2}{*}{10} & Frequency & 4 & 12 & 17 & & 22 & \multirow[t]{2}{*}{3.61} \\
\hline & Percent & $5 \%$ & $15 \%$ & $21.25 \%$ & $31.25 \%$ & $27.5 \%$ & \\
\hline \multirow[t]{2}{*}{11} & Frequency & 3 & 3 & & & & \multirow[t]{2}{*}{4.38} \\
\hline & Percent & $3.75 \%$ & $3.75 \%$ & $6.25 \%$ & $22.5 \%$ & $63.75 \%$ & \\
\hline \multirow[t]{2}{*}{14} & Frequency & & & & & & \multirow[t]{2}{*}{3.98} \\
\hline & Percent & $1.25 \%$ & $7.5 \%$ & $21.25 \%$ & $31.25 \%$ & $38.75 \%$ & \\
\hline \multirow[t]{2}{*}{15} & Frequency & & 0 & & & 53 & \multirow[t]{2}{*}{3.37} \\
\hline & Percent & $1.25 \%$ & $0 \%$ & $3.75 \%$ & $28.75 \%$ & $64.25 \%$ & \\
\hline \multirow[t]{2}{*}{16} & Frequency & & & & 4 & & \multirow[t]{2}{*}{1.71} \\
\hline & Percent & $42.5 \%$ & $28.75 \%$ & $13.75 \%$ & $5 \%$ & $10 \%$ & \\
\hline \multirow[t]{2}{*}{23} & Frequency & & & 12 & & & \multirow[t]{2}{*}{4.25} \\
\hline & Percent & $1.75 \%$ & $2.5 \%$ & $15 \%$ & $32.5 \%$ & $48.75 \%$ & \\
\hline \multirow[t]{2}{*}{24} & Frequency & 50 & 12 & & & & \multirow[t]{2}{*}{1.85} \\
\hline & Percent & $62.5 \%$ & $15 \%$ & $8.75 \%$ & $2.5 \%$ & $11.25 \%$ & \\
\hline \multirow[t]{2}{*}{27} & Frequency & 3 & 3 & & & & \multirow[t]{2}{*}{4.53} \\
\hline & Percent & $3.75 \%$ & $3.75 \%$ & $3.75 \%$ & $12.5 \%$ & $76.25 \%$ & \\
\hline \multirow[t]{2}{*}{28} & Frequency & 0 & 0 & 0 & & & \multirow[t]{2}{*}{4.82} \\
\hline & Percent & $0 \%$ & $0 \%$ & $0 \%$ & $17.5 \%$ & $82.5 \%$ & \\
\hline \multirow[t]{2}{*}{32} & Frequency & 4 & & 12 & 21 & 42 & \multirow[t]{2}{*}{4.2} \\
\hline & Percent & $5 \%$ & $1.25 \%$ & $15 \%$ & $26.25 \%$ & $52.5 \%$ & \\
\hline \multirow[t]{2}{*}{33} & Frequency & & 16 & & & & \multirow[t]{2}{*}{2.02} \\
\hline & Percent & $61.25 \%$ & $20 \%$ & $2.5 \%$ & $6.25 \%$ & $13.75 \%$ & \\
\hline \multirow[t]{2}{*}{43} & Frequency & 2 & 8 & 11 & & & \multirow[t]{2}{*}{4.10} \\
\hline & Percent & $2.5 \%$ & $10 \%$ & $13.75 \%$ & $22.5 \%$ & $51.25 \%$ & \\
\hline \multirow[t]{2}{*}{44} & Frequency & 1 & 1 & 4 & 16 & 58 & \multirow[t]{2}{*}{3.98} \\
\hline & Percent & $1.25 \%$ & $1.25 \%$ & $5 \%$ & $20 \%$ & $72.5 \%$ & \\
\hline
\end{tabular}

The learners tended to disagree with items $16(M=1.71), 24(M=1.85)$, and $33(M=2.02)$, which respectively stated that they preferred studying in their L1 rather than any other L2; that they did not like studying English; and that they really had little interest in English class. This showed the learners' interest and enthusiasm to learn English.

\subsection{Results for the Second Research Question}

The second research question investigated: "What is the relationship between Iranian teachers' beliefs and learners' attitudes?" The teachers were first divided into three groups of HOG, MG, and LOG based on their interviews. The results of this analysis are shown in the following: 
Table 4. Descriptive statistics for comparing the participants' attitude scores

\begin{tabular}{lllllllll}
\hline & $N$ & Mean & Std. Deviation & Std. Error & \multicolumn{2}{c}{ 95\% Confidence Interval for Mean } & Minimum & Maximum \\
& & & & & Lower Bound & Upper Bound \\
\hline HOG & 27 & 170.59 & 8.30 & 1.59 & 167.30 & 173.87 & 158.00 & 188.00 \\
MG & 27 & 156.48 & 8.08 & 1.55 & 153.28 & 159.67 & 143.00 & 178.00 \\
LOG & 26 & 143.84 & 11.75 & 2.30 & 139.09 & 148.59 & 126.00 & 173.00 \\
Total & 80 & 157.13 & 14.42 & 1.61 & 153.92 & 160.34 & 126.00 & 188.00 \\
\hline
\end{tabular}

The mean scores of the learners of the HOG teachers $(M=170.59)$, those of the MG teachers $(M=156.48)$, and those of the LOG teachers $(M=143.84)$ were different from one another. To find out whether the differences among these mean scores were statistically significant or not, one needs to look down the Sig. column of Table 5:

Table 5. Results of one-way ANOVA for comparing the participants' attitude scores

\begin{tabular}{llllll}
\hline & Sum of Squares & $d f$ & Mean Square & $F$ & Sig. \\
\hline Between Groups & 9492.84 & 2 & 4746.42 & 52.61 & .000 \\
Within Groups & 6946.64 & 77 & 90.21 & & \\
Total & 16439.48 & 79 & & & \\
\hline
\end{tabular}

As is shown in Table 5, there was a statistically significant difference in the learners' attitude scores for HOG ( $M$ $=170.59, S D=8.30)$, MG $(M=156.48, S D=8.08)$, and LOG $(M=143.84, S D=11.75)$ because the $p$-value under the Sig. column was less than the level of significance (i.e., .000<.05). To see where exactly the differences among the groups lie, the Scheffe post-hoc test table was checked (see Table 6):

Table 6. Post-hoc Scheffe test results comparing the participants of the three groups

\begin{tabular}{lllllll}
\hline & & Mean Difference & Std. Error & Sig. & \multicolumn{2}{c}{$95 \%$ Confidence Interval } \\
& & & & & Lower Bound & Upper Bound \\
\hline HOG & MG & $14.11^{*}$ & 2.58 & .000 & 7.65 & 20.56 \\
& LOG & $26.74^{*}$ & 2.60 & .000 & 20.23 & 33.26 \\
\multirow{2}{*}{ MG } & HOG & $-14.11^{*}$ & 2.58 & .000 & -20.56 & -7.65 \\
& LOG & $12.63^{*}$ & 2.60 & .000 & 6.12 & 19.14 \\
LOG & HOG & $-26.74^{*}$ & 2.60 & .000 & -33.26 & -20.23 \\
& MG & $-12.63^{*}$ & 2.60 & .000 & -19.14 & -6.12 \\
\hline
\end{tabular}

The conclusion which could be drawn from this observation is that the learners of the HOG teachers $(M=170.59)$ gained significantly higher attitude scores than the learners of the MG teachers $(M=156.48)$ because their teachers held more positive beliefs about language learning. In turn, the learners of the MG teacher could obtain higher attitude scores than those of the LOG teachers $(M=143.84)$ because their teachers' beliefs about language learning were comparatively more positive than those of the teachers in the LOG. In a nutshell, EFL teachers' beliefs can influence their learners' attitudes about language learning. This is also graphically shown in Figure 1: 


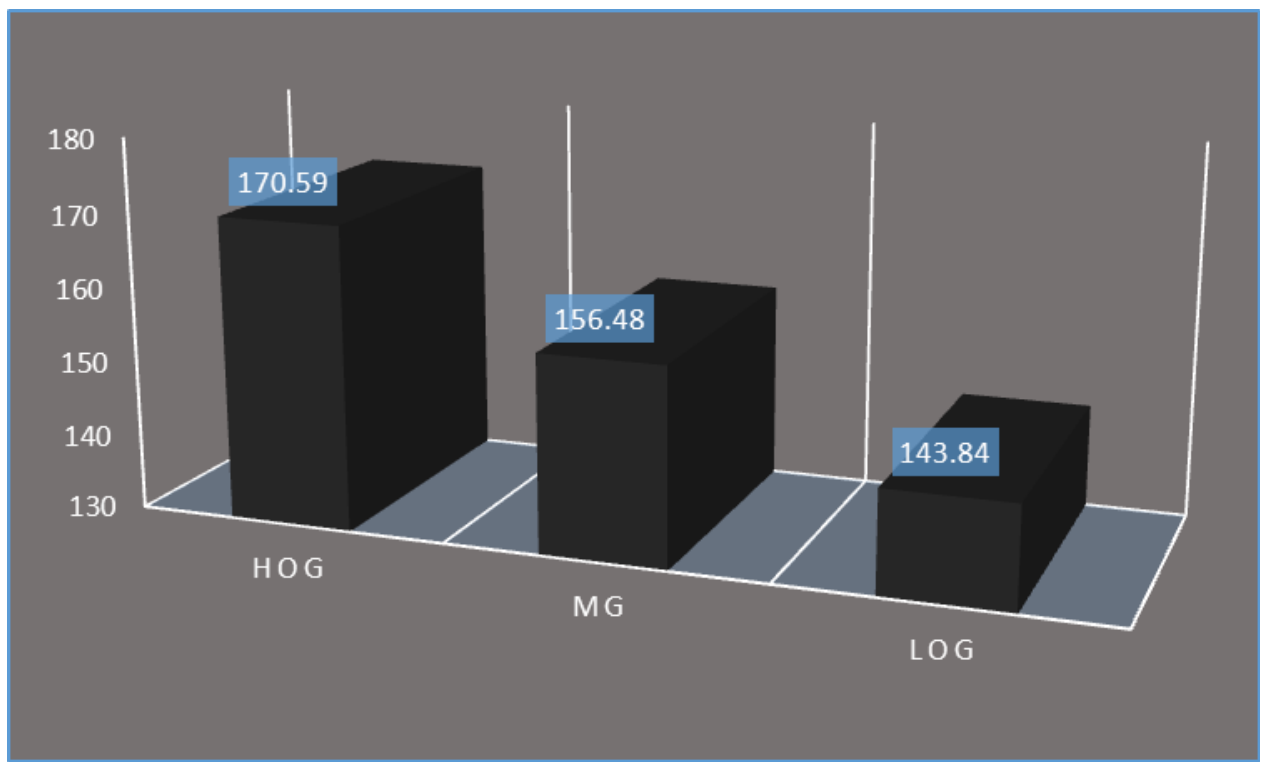

Figure 1. Learners' attitude scores of the HOG, MG, and LOG teachers

As is obvious and as it was mentioned above, regarding attitude scores, the learners of the HOG teachers outperformed the learners of the MG teachers who, in turn, could get higher scores than the learners of the LOG teachers.

\section{Discussion}

The result of this study showed that the Iranian EFL learners' attitude in terms of behavioral, cognitive, and emotional aspects was positive toward learning English, and there was a direct relationship between the Iranians teachers' beliefs and learners' attitude.

It was found that the Iranian EFL learners' attitude toward learning English was positive. A possible explanation for such findings can be attributed to the fact that regarding the aforementioned research studies, it became evident that attitude and perception play significant roles in enabling L2 learners to learn effectively.

This must be taken into consideration, particularly due to the fact that when students' beliefs and performance do not match, they become frustrated and disappointed with the class and with themselves resulting in hindrance in the intake of the materials. In accordance with Brown (2007), the results of the current study study puts emphasis on the fact that teachers need to bear in mind that everyone has both positive and negative attitudes. The fact that if L2 students are trained by some more motivated teachers who hold more positive beliefs about language learning, there will also be better teaching outcomes, as there may be more positive attitudes among L2 students' of that specific teacher.

The results of this study were in line with $\mathrm{Li}$ (2008) in that Li demonstrated a strong sense of the importance of teachers' beliefs in language learning/teaching and its effects on the attitude of L2 learners. Moreover, in accordance with Borg (2006), this study found that there is a one-to-one relationship between teachers' and students' beliefs; the interactions with students appeared to be much more closely guided by local, contextual issues. This could be due to the positive and healthy atmosphere of the class.

Learners' attitudes and beliefs are in the process of being added to the increasing body of research in the area of language teaching. The moment that L2 learners set their feet in a language classroom, they bring all their personality traits along including their beliefs, attitudes, and language styles in order to learn a language. These features, however, may differ from that of teachers.

The concept of learners' attitudes has been the focus of attention in explanation and investigation of human behavior offered by social psychologists. Attitude is usually defined as a disposition or tendency to respond positively or negatively towards a certain thing such as an idea, object, person, or situation. Students have positive or negative attitudes towards the language they want to learn or the people who speak it (Malallaha, 2000). 
It seems that a large number of studies have investigated teachers' beliefs in the field of language teaching (Bachman, 1990; Coleman, Strafield, \& Hagan, 2003; Malallaha, 2000), but not its interaction with learners' attitude which is a very important factor. Gardner (1985) believes that attitude and other affective variables are as important as the aptitude for language achievement.

\section{Conclusion}

It was found that the Iranian EFL learners' attitude toward learning English in terms of behavioral, cognitive, and emotional aspects was positive. A possible explanation for such findings can be attributed to the fact that regarding the aforementioned research studies, it became evident that attitude and perception play significant roles in enabling learners to learn effectively. As it was stated, L2 learners' attitude, the type of task at hand, cultural background and previous experiences are all contributive to the way learners behave toward and perceive learning strategies and their ability in maintaining higher levels of learning.

In accordance with Brown (2007), the results of this study puts emphasis on the fact that teachers need to bear in mind that everyone has both positive and negative attitudes. Negative attitudes usually emerge from one's indirect exposure to a culture or group through books or media and they often can be changed by exposure to reality. Therefore, it can be concluded that having positive or negative attitudes towards a certain language and the way learners perceive that language can exert considerable influence upon their performance on the language itself.

Such findings can be explained by the fact that if L2 students are trained by some more motivated teachers who hold more positive beliefs about language learning, we will also have better teaching outcomes, as there may be more positive attitudes among the students' of that teacher.

By focusing on this complex inter-relationship between stated beliefs and actions while teaching, researchers offer not only detailed understandings of teachers' beliefs, but also the potential to understand more the relationship between teachers' and students' beliefs and attitudes (Speer, 2005). Rather than having a single, straightforward and linear relationship between L2 students' attitudes and teachers' beliefs, we can form a picture which is much more complicated (Borg, 2006; Li, 2008; Sato, \& Kleinsasser, 2004).

\section{Implications}

If learning to teach is acknowledged as a complex process, then teachers need various opportunities to understand the implementation of their beliefs and their interaction with L2 students' attitude. Language teachers should learn about the effect of their beliefs and experience it and become more aware of practicing them. Teachers need to receive continuous professional development and support to increase the possibility of implementing their ideas. In the absence of any regular reform of science teaching, it is most probable that candidate teachers will continue to join teacher education programs with naive views of the scientific endeavor (Lederman \& Latz, 1995, Stofflet \& Stoddart, 1994). As such, science teacher education programs should continue their attempts to promote more adequate conceptions of teachers' beliefs and its effects on teaching practices and L2 learners' attitudes.

To encapsulate, it is hoped that the results of this study help L2 instructors and researchers follow better ways of approaching psychological and hidden features of both L2 teachers and students. Also, the findings may bear a part in saving the attention to beliefs and attitudes from the danger of extinction in L2 curricula and material development by exploring their relationship between the role of teachers' beliefs and learners' attitude.

\section{Limitations}

Like any other research, this study is not without limitations. Firstly, the data collection in this study was filtered by many careful measures and precautions. Nevertheless, due to the limited and small scale of this research project, along with the inevitable restrictions bound with the exploration of such a covert and somewhat imperceptible cognitive process that takes place in people's minds, it needs to be noted that the results obtained through this study need to be understood as only suggestive of trends and patterns. The other limitation was all of the participants in the study were adult language learners which could be regarded as a potential limitation of the study. A study carried out with a wider range of subjects could enhance the possibility of analyzing and interpreting the results within a larger domain. The other limitation was since there was no access to a sufficient number of native speakers of different languages, the researcher had to include participants from a single language background, that is, Farsi. In a more extensive study of this kind, language learners with various language backgrounds can be selected and assigned to separate groups of instruction. 


\section{References}

Almarza, G. G. (1996). Student foreign language teacher's knowledge growth. In D. Freeman, \& J. C. Richards (Eds.), Teacher learning in language teaching (pp. 50-78). Cambridge, UK: Cambridge University Press.

Al-Tamimi, A., \& Shuib, M. (2009). Motivation and attitudes towards learning English: A study of petroleum engineering undergraduates at Hadhramout University of Sciences and Technology. Retrieved May 10, 2015, from the World Wide Web: http:/www.ukm.my/ppbl/Gema/ abstract/pdf

Bachman, L. (1990). Fundamental considerations in language testing. Oxford: Oxford University Press.

Boonrangsri, K., Chuaymankhong D., Rermyindee N., \& Vongchittpinyo, N. (2004). The attitude towards English language learning of the students in vocational certificate level under curriculum in 2002: A case study of Ayutthaya Technical College. Thailand: Naresuan University

Borg, S. (2003). Teacher cognition in language teaching: A review of research on what language teachers think, know, believe, and do. Language Teaching, 36, 81-109. http://dx.doi.org/10.1017/S0261444803001903

Borg, S. (2006). Teacher education and language education: Research and practice. London and New York: Continuum.

Brown, D. H. (2007). Principles of language learning and teaching (5th ed.). Pearson: Longman.

Calderhead, J. (1996). Teachers: Beliefs and knowledge. In D. Berliner, \& Calfee (Eds.), Handbook of educational psychology. New York: Macmillan Library Reference.

Canagarajah, A. S. (2005). Reclaiming the local in language policy and practice. Mahwah, NJ: Lawrence Erlbaum.

Choy, S. C., \& Troudi, S. (2006). An investigation into the changes in perceptions of and attitudes towards learning English in a Malaysian college. International Journal of Teaching and Learning in Higher Education, 18(2), 120-130.

Clark, C. M., \& Peterson P. L. (1986). Teachers' thought processes. In M. C. Wittrock (Ed.), Handbook of research on teaching ( $3^{\text {rd }}$ ed.; pp. 255-96). New York: Macmillan.

Coleman, D., Strafield, S., \& Hagan, A. (2003). The attitudes of IELTS stakeholders: Student and staff apperception of IELTS in Australian, UK, and Chinese tertiary institutions. IELTS Australia Research, 5, 20-34.

Donaghue, H. (2003). An instrument to elicit teachers' beliefs and assumptions. ELT Journal, 57(4), 344-351.

Dörnyei, Z. (1994). Motivation and motivating in the foreign language classroom. Modern Language Journal, 78, 273-284. http://dx.doi.org/10.1111/j.1540-4781.1994.tb02042.x

Erkmen, B. (2010). Nonnative EFL teachers' beliefs about teaching and learning. Unpublished doctoral dissertation, University of Notthingham, England.

Gardner, R. (1985). Social psychology and second language learning. The role of attitudes and motivation. London: Edward Arnold.

Hassan, B. (1996). Attitudinal variables and EFL proficiency among Arabic speaking college students. Mansoura Faculty of Education Journal, 30, 47-77.

Kara, A. (2009). The effect of a learning theories unit on students' attitudes towards learning. Australian Journal of Teacher Education, 34(3), 100-113. http://dx.doi.org/10.14221/ajte.2009v34n3.5

Kim, M., \&Mcgarry, T. (2014). Attitudes to storytelling among adult ESL learners. Journal of Language Teaching and Learning, 4(1), 15-36.

Lederman, N. G., \&Latz, M. S. (1995). Knowledge structures in the preservice science teacher; sources, development, interactions, and relationships to teaching. Journal of Science Teacher Education, 6, 1-19. http://dx.doi.org/10.1007/BF02614542

Li, M. (2008). Routledge encyclopedia of language teaching and learning. London: Routledge.

Maiklad, C. (2001). The beliefs and practices of Thai English language teachers. Unpublished doctoral dissertation, University of Exeter, UK. 
Malallaha, S. (2000). English in an Arabic environment: Current attitudes to English among Kuwait University students. International Journal of Bilingual Education and Bilingualism, 3, 19-43. http://dx.doi.org/10.1080/13670050008667698

Mangubhai, F., Marland, P., Dashwood, A., \& Son, J. B. (2004). Teaching a foreign language: One teacher's practical theory. Teaching and Teacher Education, 20(3), 291-311. http://dx.doi.org/10.1016/j.tate.2004.02.001

Nespor, J. (1987). The role of beliefs in the practice of teaching. Journal of Curriculum Studies, 19(4), 317-328. http://dx.doi.org/10.1080/0022027870190403

Ng, E. K. J., \& Farrell, T. S. C. (2003). Do teachers' beliefs of grammar teaching match their classroom practices? A Singapore case study. In D. Deterding, A. Brown, \& E. L. Brown (Eds.), English in Singapore: Research on grammar (pp. 128-143). Singapore: McGraw Hill.

Reid, N. (2003). Getting started in pedagogical research in the physical sciences. University of Hull, Hull: LTSN Physical Sciences Center.

Sato, K., \& Kleinsasser, R. C. (2004). Communicative language teaching (CLT): Practical understandings. The Modern Language Journal, 83(4), 494-517. http://dx.doi.org/10.1111/0026-7902.00037

Soleimani, H., \& Hanafi, S. (2013). Iranian medical students' attitudes towards English language learning. International Research Journal of Applied and Basic Sciences, 4(12), 16-23.

Speer, J. R. (2005). The expression of attitude. New York: Springer-Verlag.

Stofflet, R., \&Stoddart, T. (1994). The ability to understand and use conceptual change pedagogy as a function of prior. Journal of Research in Science Teaching, 31, 31-51. http://dx.doi.org/10.1002/tea.3660310105

Tillema, H. H. (2000). Belief change towards self-directed learning in student teachers: Immersion in practice or reflection on action. Teaching and Teacher Education, 16, 575-91. http://dx.doi.org/10.1016/S0742-051X(00)00016-0

Victori, M., \& Lockhart, W. (1995). Enhancing metacognition in self-directed language learning. System, 23, 223-234. http://dx.doi.org/10.1016/0346-251X(95)00010-H

Visser, M. (2008). Learning under conditions of hierarchy and discipline: The case of the German Army (1939-1940). Learning Inquiry, 2, 127-137. http://dx.doi.org/10.1007/s11519-008-0031-7

Wenden A. (1991). Learner strategies for learner autonomy. London: Prentice Hall.

Zainol Abidin, M. J., Pour-Mohammadi, M., \& Alzwari, H. (2012). EFL students' attitudes towards learning English language: The case of Libyan secondary school students. Asian Social Science, 8(2), 119-134. http://dx.doi.org/10.5539/ass.v8n2p119 


\section{Appendix}

\section{Attitudes of Iranian EFL Students Towards Learning English Language Questionnaire}

NOTE: Dear student, the main goal of this study is to investigate the attitudes of Iranian EFL students towards learning the English language in terms of the behavioral, cognitive and emotional aspects of attitude. Your answers will help EFL teachers and educators to understand EFL learners' needs and overcome any difficulties and challenges they may have with English language.

\section{Attitudes Towards English Language}

Directions: To what extent do you agree with the following items? The following items ask about your attitudes toward learning the English language. Remember there is no right or wrong answers; just answer as accurately as possible. Please read the statements below carefully and tick the appropriate choices that reflect your attitudes and perceptions towards English language. Use the scale below to answer the questionnaire items.

1 (Strongly Disagree), 2 (Disagree), 3 (Neutral), 4 (Agree), 5 (Strongly Agree)

Note: Tick $(\sqrt{ })$ only one option for each item in the questionnaire.

\begin{tabular}{|c|c|c|c|c|c|c|}
\hline NO & Items & $\mathbf{1}$ & 2 & $\mathbf{3}$ & 4 & 5 \\
\hline 1 & Studying English is important because it will make me more educated & & & & & \\
\hline 2 & Being good at English will help me study other subjects well & & & & & \\
\hline 3 & I feel proud when studying English language & & & & & \\
\hline 4 & I feel excited when I communicate in English with others & & & & & \\
\hline 5 & Speaking English anywhere makes me feel worried & & & & & \\
\hline 6 & Studying English helps me to have good relationships with friends & & & & & \\
\hline 7 & I like to give opinions during English lessons. & & & & & \\
\hline 8 & I have more knowledge and more understanding when studying English & & & & & \\
\hline 9 & I look forward to studying more English in the future & & & & & \\
\hline 10 & $\begin{array}{l}\text { I don't get anxious when I have to answer a question in my English } \\
\text { class }\end{array}$ & & & & & \\
\hline 11 & Studying foreign languages like English is enjoyable & & & & & \\
\hline 12 & I am able to make myself pay attention during studying English & & & & & \\
\hline 13 & $\begin{array}{l}\text { When I hear a student in my class speaking English well, I like to } \\
\text { practice speaking with him or her }\end{array}$ & & & & & \\
\hline 14 & To be inquisitive makes me study English well & & & & & \\
\hline 15 & Studying English makes me have good emotions ( feelings) & & & & & \\
\hline 16 & $\begin{array}{l}\text { I prefer studying in my mother tongue rather than any other foreign } \\
\text { language }\end{array}$ & & & & & \\
\hline 17 & Studying English makes me have more confidence in expressing myself & & & & & \\
\hline 18 & Studying English helps me to improve my personality & & & & & \\
\hline 19 & I put off my English homework as much as possible & & & & & \\
\hline 20 & $\begin{array}{l}\text { Studying English helps me getting new information in which I can link } \\
\text { to my previous knowledge }\end{array}$ & & & & & \\
\hline 21 & $\begin{array}{l}\text { I cannot to summarize the important points in the English subject } \\
\text { content by myself }\end{array}$ & & & & & \\
\hline 22 & Frankly, I study English just to pass the exams. & & & & & \\
\hline 23 & I enjoy doing activities in English & & & & & \\
\hline 24 & I do not like studying English & & & & & \\
\hline 25 & I am not relaxed whenever I have to speak in my English class & & & & & \\
\hline 26 & I feel embarrassed to speak English in front of other students & & & & & \\
\hline 27 & I wish I could speak English fluently. & & & & & \\
\hline
\end{tabular}




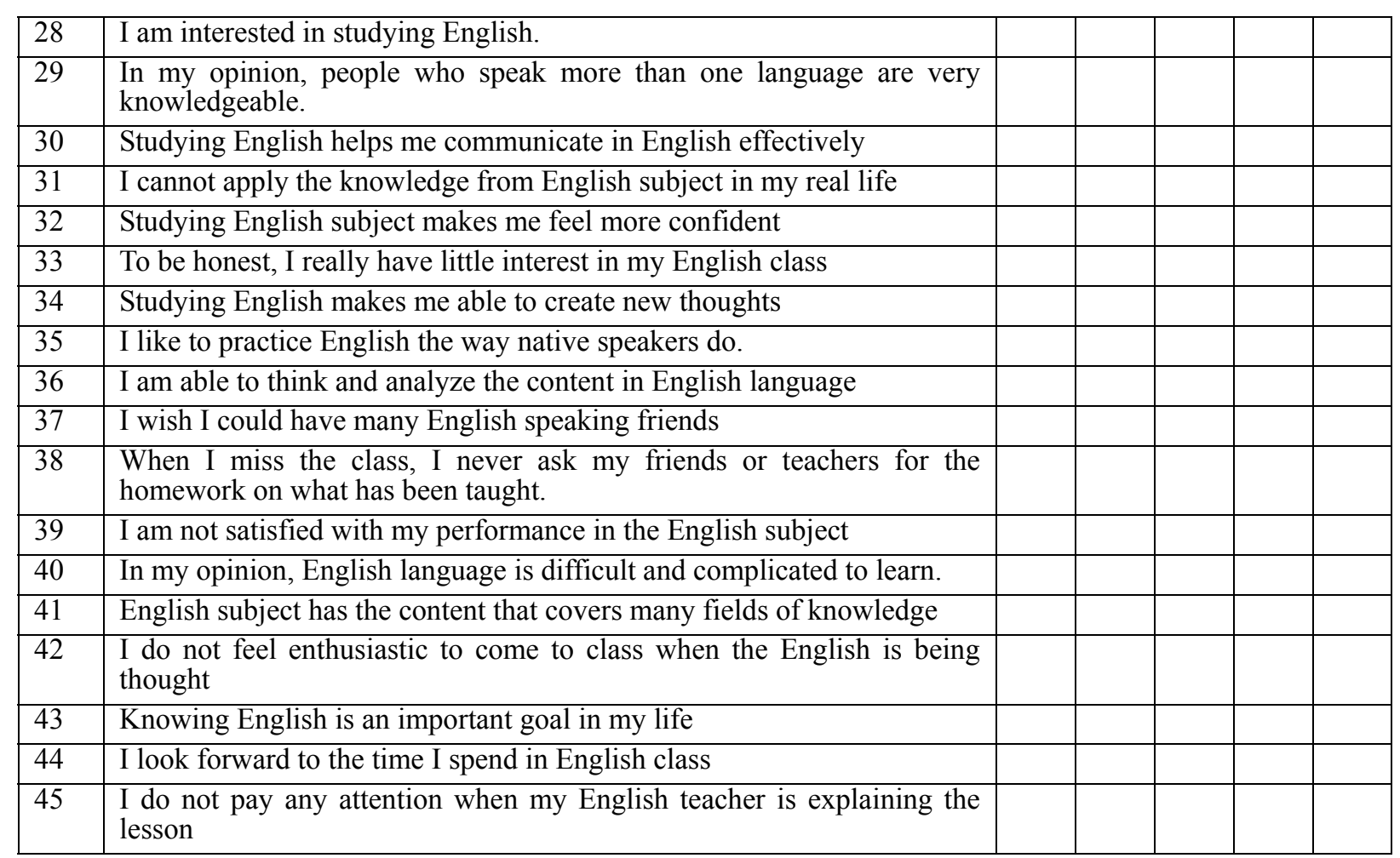

\section{Copyrights}

Copyright for this article is retained by the author(s), with first publication rights granted to the journal.

This is an open-access article distributed under the terms and conditions of the Creative Commons Attribution license (http://creativecommons.org/licenses/by/3.0/). 